\title{
Elevation of serum phosphorus, an early biomarker of acute kidney injury after cardiac sugery?
}

\author{
J Ridolfo, M Saour ${ }^{*}$, G Culas, N Zeroual, G Samarani, P Gaudard, P Colson \\ From ESICM LIVES 2015 \\ Berlin, Germany. 3-7 October 2015
}

\section{Introduction}

Acute kidney injury (AKI) is common after cardiac surgery and is a strong predictor of morbidity and mortality [1]. Hyperphosphatemia following AKI, by renal excretion defect, has never been studied in this context and could be a simple marker of AKI.

\section{Objectives}

The aim of this study was to assess the predictability of serum phosphorus $(\mathrm{Ph})$ for AKI monitoring after cardiac surgery.

\section{Methods}

In this retrospective diagnostic validation study of 547 patients admitted in our institute between January 2012 and December 2012, we excluded patients with end stage renal disease (clearance $<15 \mathrm{~mL} / \mathrm{min} / 1.73 \mathrm{~m} 2$ ) or dialyzed, solitary kidney or nephrectomy, lack of data. Serum creatinine $(\mathrm{Cr})$ and $\mathrm{Ph}$ were measured preoperatively and postoperatively specifically (H0, H12, H24, H48, H72). The percentage of maximum elevation of $\mathrm{Ph}(\% \mathrm{EPh}=$ [(maximum -minimum) / minimum] " 100) was calculated. AKI was defined as an increase $\mathrm{Cr}$ more than 26.5 $\mathrm{mmol} / \mathrm{L}$ in 48 hours according to KDIGO criteria [2]. The diagnostic performance of postoperative Ph thresholds were analysed by elaborating area under the receiver operating characteristic curves (AUC-ROC) with sensitivity $(\mathrm{Se})$, specificity $(\mathrm{Sp})$, positive predictive value (PPV), negative predictive value (NPV).

\section{Results}

From the 386 patients included, the mean Euroscore II was $4.2 \pm 6.3 \%$, SAPS II score, $26.4 \pm 10.8$. Among

Arnaud de Villeneuve University Hospital, Department of Anesthesiology and Intensive Care, Montpellier, France them, 21.2\% developed AKI (grade 1: 13.2\%, grade 2: $4.1 \%$, grade $3: 3.1 \%$ ) and $2.6 \%$ required renal replacement therapy (RRT). Patients with AKI had Euroscore II, duration of cardiopulmonary bypass, transfusion needing and mortality higher than those without AKI $(\mathrm{p}<0.001)$. The \%EPh and the $\mathrm{Ph}$ at 48 hours $\left(\mathrm{Ph}_{48 \mathrm{H}}\right)$ were significantly higher in AKI patients than in no AKI patients: $81 \pm 79 \%$ and $1.47 \pm 0.46 \mathrm{mmol} / \mathrm{l}$ vs $25 \pm 23 \%$ and $0.99 \pm 0.2 \mathrm{mmol} / \mathrm{L}$, respectively $(\mathrm{p}<0.001)$. A value of $\mathrm{Ph}_{48 \mathrm{H}}>1.19 \mathrm{mmol} / \mathrm{L}$ ( Se 72\% (60-82), Sp 84\% (7192), PPV 84\%, NPV 72\%) and a \%EPh > $49 \%$ (Se 73\% (61-81), Sp 83\% (76-88), PPV 66\%, NPV 86\%) were predictive of AKI. In AKI patients, the \%EPh and $\mathrm{Ph}_{48 \mathrm{H}}$ significantly increased with the severity of AKI (Table 1). In these patients, a $\mathrm{Ph}_{48 \mathrm{H}}<1.53 \mathrm{mmol} / \mathrm{L}$ and a $\% \mathrm{EPh}<$ $77 \%$ predicted the non use of RRT (Se 100\% (62-100), Sp 85\% (77-91), PPV 35\% NPV 100\%), respectively (Table 2).

\section{Conclusions}

After cardiac surgery, serum phosphorus seems to be a simple, reliable and inexpensive biomarker at bedside for AKI monitoring. A value less than $1.53 \mathrm{mmol} / \mathrm{L}$ at $48 \mathrm{~h}$ may predict the no-initiation of RRT in case of AKI and may guide the clinician to a non-invasive-AKI therapeutic. Obviously, these results should be interpreted with caution regarding the retrospective nature of the study.

\section{Table 1}

\begin{tabular}{lll}
\hline AKI severity & \%EPh & Ph $_{\mathbf{4 8 H}}$ ( $\left.\mathbf{m m o l} / \mathbf{L}\right)$ \\
\hline Grade 1 & $60 \pm 45$ & $1.25 \pm 0.4$ \\
\hline Grade 2 & $74 \pm 58$ & $1.73 \pm 0.4$ \\
\hline Grade 3 & $159 \pm 132$ & $1.80 \pm 0.5$ \\
\hline
\end{tabular}


Table 2

\begin{tabular}{|c|c|c|c|}
\hline & Thresholds & AUC (IC95\%) & $p$ value \\
\hline \multicolumn{4}{|c|}{ AKI diagnostic } \\
\hline $\mathrm{Ph}_{48 \mathrm{H}}$ & $1.19 \mathrm{mmol} / \mathrm{L}$ & $0.813(0.735-0.890)$ & $<0.0001$ \\
\hline \%EPh & $49 \%$ & $0.830(0.772-0.889)$ & $<0.0001$ \\
\hline \multicolumn{4}{|c|}{ RRT requiring } \\
\hline $\mathrm{Ph}_{48 \mathrm{H}}$ & $1.53 \mathrm{mmol} / \mathrm{L}$ & $0.924(0.879-0.970)$ & $<0.0001$ \\
\hline \%EPh & $77 \%$ & $0.818(0.683-0.952)$ & $<0.0001$ \\
\hline
\end{tabular}

Published: 1 October 2015

\section{References}

1. Lassnigg A, Schmidlin D, Mouhieddine M, Bachmann LM, Druml W, Bauer P, et al: Minimal changes of serum creatinine predict prognosis in patients after cardiothoracic surgery: a prospective cohort study. J Am Soc Nephrol 2004, 15:1597-1605.

2. Kidney Disease: Improving Global Outcomes (KDIGO) Acute Kidney Injury Work Group. KDIGO Clinical Practice Guideline for Acute Kidney Injury. Kidney Inter 2012, Suppl 2:1-138.

doi:10.1186/2197-425X-3-S1-A465

Cite this article as: Ridolfo et al: Elevation of serum phosphorus, an early biomarker of acute kidney injury after cardiac sugery? Intensive Care Medicine Experimental 2015 3(Suppl 1):A465.

\section{Submit your manuscript to a SpringerOpen ${ }^{\circ}$ journal and benefit from:}

- Convenient online submission

- Rigorous peer review

- Immediate publication on acceptance

- Open access: articles freely available online

- High visibility within the field

- Retaining the copyright to your article

Submit your next manuscript at $>$ springeropen.com 